\title{
Profil Pemecahan Masalah SPLDV Berdasarkan Kemampuan Metakognisi Siswa Ditinjau dari Self Regulated Learning
}

Author:
Pramesthya Dwi
Retnaninggalih $^{1}$
Dinawati Trapsilasiwi ${ }^{2}$
Inge Wiliandani Setya Putri ${ }^{3}$
Affiliation:
${ }^{1}$ University of Jember, East
Java, Indonesia
Corresponding author:
Pramesthya Dwi
Retnaninggalih,
prameshretna76@ gmail.com
Dates:
Received: $24 / 2 / 2021$
Accepted: 6/3/2021
Published: $16 / 3 / 2021$

\section{Author:}

Dinawati Trapsilasiwi

Affiliation:

${ }^{1}$ University of Jember, East

Java, Indonesia

\section{Corresponding author:}

Pramesthya Dwi

Retnaninggalih, prameshretna76@gmail.com

\section{Dates:}

Accepted: 6/3/2021

Published: $16 / 3 / 2021$

\begin{abstract}
Abstrak. Penelitian ini bertujuan untuk mendeskripsikan profil pemecahan masalah SPLDV berdasarkan kemampuan metakognisi siswa ditinjau dari self regulated learning. Penelitian dilakukan di kelas VIII B SMP Negeri 1 Genteng yang terdiri dari 33 siswa. Instrumen yang digunakan terdiri dari angket self regulated learning, tes pemecahan masalah matematika, pedoman wawancara, dan lembar validasi. Subjek yang dipilih sebagai responden wawancara adalah 2 siswa dari setiap kategori self regulated learning yang memiliki perbedaan signifikan pada skor angket self regulated learning, skor tes, dan keakuratan jawaban pada tes pemecahan masalah matematika. Siswa dengan self regulated learning tinggi yakni N1 memiliki skor angket 129 dan skor tes 32, sedangkan N2 memiliki skor angket 127 dan skor tes 32 . Siswa dengan self regulated learning sedang yakni N3 memiliki skor angket 108 dan skor tes 23, sedangkan N4 memiliki skor angket 97 dan skor tes 22. Siswa dengan self regulated learning rendah yakni N5 memiliki skor angket 69 dan skor tes 14, sedangkan N6 memiliki skor angket 56 dan skor tes 17.
\end{abstract}

Kata kunci: Pemecahan Masalah, Kemampuan Metakognisi, Self Regulated Learning

\begin{abstract}
This study aims to describe the profile of SPLDV management problems based on students' metacognitive abilities in terms of independent learning. The research was conducted in class VIII B of SMP Negeri 1 Genteng which consisted of 33 students. The instruments used consisted of selfregulated learning questionnaires, tests of math problems, recent interviews, and validation sheets. The subjects selected as interview respondents were 2 students from the self-regulated learning category who had significant differences in the independent learning questionnaire scores, test scores, and answer accuracy on each test of math problems. Students with high selflearning namely N1 had a questionnaire score of 129 and a test score of 32, while N2 had a questionnaire score of 127 and a test score of 32 .Students with independent learning, namely N3 had a questionnaire score of 108 and a test score of 23, while N4 had a questionnaire score of 97 and a score of 32. test 22. Students with low self-regulated learning, namely N5 have a questionnaire score of 69 and a test score of 14, while N6 has a questionnaire score of 56 and a test score of 17.
\end{abstract}

Keywords: Problem solving, metakognisi skill, self regulated learning

\section{JoM}

This work is licensed under a Creative Commons Attribution-ShareAlike 4.0 International License.

Read online:

https://jurnal.unej.ac.id/index.php/JOMEAL/index

or scan barcode beside.

How to cite this article:

Retnaninggalih, P., Trapsilasiwi, D., \& Putri, I. (2021). Profil Pemecahan Masalah SPLDV Berdasarkan Kemampuan

Metakognisi Siswa Ditinjau dari Self Regulated Learning. Journal Of Mathematics Education And Learning, 1(1), 20-

26. Retrieved from https://jurnal.unej.ac.id/index.php/JOMEAL/article/view/24372 


\section{Pendahuluan}

Pemecahan masalah dalam matematika berarti suatu kegiatan untuk mencari penyelesaian atau solusi dari masalah matematika menggunakan semua bekal pengetahuan matematika yang dimiliki (Cahyani \& Setyawati, 2016). Terdapat tiga syarat suatu masalah dikatakan sebagai pemecahan masalah yakni 1) masalah tersebut belum diketahui bagaimana prosedur meyelesaikannya, 2) masalah tersebut sesuai dengan tingkat berpikir dan pengetahuan prasyarat siswa, dan 3) siswa memiliki niat untuk menyelesaikan masalah tersebut (Ruseffendi, 2006). Mayer mendefinisikan pemecahan masalah sebagai proses yang disertai dengan banyaknya langkah di mana seseorang yang ingin memecahkan masalah tersebut harus menemukan hubungan antara pengalaman di masa lalu dengan masalah yang sedang dihadapinya dan dilanjutkan dengan bertindak untuk menyelesaikannya (Widjajanti, 2009). Saat pemecahan masalah matematika dilakukan, maka siswa dihadapkan dengan beberapa tantangan seperti kesulitan dalam memahami soal, sehingga diperlukan langkah-langkah dalam penyelesaian soal agar mendapatkan hasil dan manfaat yang optimal seperti yang telah dikemukakan oleh Polya yang terdiri dari memahami masalah, membuat rencana penyelesaian, melaksanakan rencana penyelesaian, dan memeriksa kembali solusi yang telah didapatkan (Novita, 2018). Tujuan dari mempelajari pemecahan masalah bagi setiap siswa yakni memiliki kemampuan untuk mengamati dan mengevaluasi pemikirannya sendiri ketika menyelesaikan masalah yang sedang dihadapi di mana aktivitas tersebut merupakan bagian dari metakognisi. Flavell mengatakan bahwa metakognisi adalah thinking about thinking atau pemantauan dan pengendalian pikiran sehingga istilah tersebut mengacu pada kemampuan seseorang untuk merencakan, memonitor, dan mengevaluasi suatu proses belajar yang sedang dilakukannya (Kuzzle, 2013). Dapat dikatakan bahwa setidaknya ada tiga indikator dalam kemampuan metakognisi yakni indikator perencanaan, pemantauan, dan penilaian (Arum, 2017). Kemampuan melakukan monitoring dan kontrol terhadap proses berpikirnya sendiri merupakan suatu keterampilan yang dapat dikembangkan dalam diri seseorang melalui pengaturan diri (self regulation). Self regulation bukanlah suatu keterampilan dalam akademik, melainkan suatu cara mengatur proses belajar individu secara mandiri melalui perencanaan, pengaturan, dan pencapaian tujuan. Proses seseorang dalam mengatur diri sendiri dalam belajar seperti menentukan tujuan belajar dan strategi yang digunakan dalam belajar disebut dengan self regulated learning (Zimmerman, 1990). Self regulated learning menegaskan pentingnya otonomi dan tanggung jawab pribadi dalam melakukan kegiatan belajar. Kegiatan ini dilakukan oleh individu yang memiliki kecintaan terhadap belajar, keingintahuan yang tinggi, dan tidak takut terhadap tantangan sehingga tujuan belajar dapat tercapai. Setiap individu yang melakukan kegiatan belajar mandiri dituntut untuk memiliki tanggung jawab yang besar dan memiliki kebiasaan mengatur dan mengelola aktivitas belajarnya baik dari segi bahan ajar, tempat, waktu, dan sumber belajar yang dibutuhkan.

Menurut penelitian yang ada analisis metakognisi siswa dalam pemecahan masalah aritmatika sosial yang ditinjau dari perbedaan gender memiliki hasil berbeda antara siswa laki-laki dan perempuan yakni siswa laki-laki belum memenuhi tiga tahapan metakognisi di mana siswa dapat memahami masalah matematika akan tetapi tidak bisa menuliskannya dengan benar, pun mereka tidak menyadari bahwa strategi yang digunakan kurang tepat sehingga di bagian evaluasi tidak dilakukan pengecekan ulang terhadap pekerjaannya. Berbeda dari hal tersebut, siswa perempuan dapat memenuhi tahapan metakognisi di mana mereka dapat memahami masalah matematika dengan baik dan dapat menuliskannya dengan benar sehingga strategi yang digunakan juga tepat karena pada bagian evaluasi mereka melakukan pengecekan ulang terhadap pekerjaannya. Selain itu, adapun 
penelitian yang dilakukan oleh Zamnah (2017) menunjukkan bahwa terdapat hubungan antara self regulated learning siswa dengan kemampuan pemecahan masalah matematis siswa. Pada umumnya, permasalahan matematika yang sulit dipahami oleh siswa yakni permasalahan dalam kehidupan sehari-hari yang biasanya disajikan dalam bentuk soal cerita. Sistem Persamaan Linear Dua Variabel (SPLDV) merupakan salah satu contoh pokok bahasan yang permasalahannya disajikan dalam bentuk soal cerita dan siswa diminta untuk memahami permasalahan terlebih dahulu sebelum menuliskan langkah-langkah selanjutnya pada lembar jawaban. Hal ini menunjukkan bahwa kemampuan metakognisi penting bagi setiap siswa untuk melakukan pemecahan masalah matematika dengan mengendalikan aktivitas belajarnya sendiri, maka peneliti tertarik melakukan penelitian tentang bagaimana cara siswa melakukan pemecahan masalah matematika pokok bahasan SPLDV menurut tahapan Polya berdasarkan kemampuan metakognisi yang dimiliki oleh siswa di mana kemampuan metakognisi tersebut ditinjau dari self regulated learning. Oleh karena itu, peneliti memilih judul "Profil Pemecahan Masalah SPLDV Berdasarkan Kemampuan Metakognisi Siswa Ditinjau dari Self Regulated Learning”.

\section{Metode Penelitian}

Jenis penelitian ini termasuk ke dalam penelitian deskriptif dengan pendekatan kualitatif dan digunakan untuk mendeskripsikan profil pemecahan masalah SPLDV menggunakan langkah-langkah Polya berdasarkan kemampuan metakognisi yang dimiliki oleh siswa ditinjau dari self regulated learning. Subjek dari penelitian ini adalah siswa dari kelas VIII B SMP Negeri 1 Genteng yang terdiri dari 33 siswa. Data penelitian didapatkan dari tiga instrumen yang terdiri dari angket self regulated learning, tes pemecahan masalah matematika, dan wawancara.

Instrumen pertama yakni angket self regulated learning yang terdiri dari 30 butir pertanyaan positif dan negatif. Oleh karena angket dibuat oleh peneliti, maka perlu dilakukan uji validitas dan reliabilitas terlebih dahulu sebelum digunakan. Instrumen kedua yakni tes pemecahan masalah matematika yang terdiri dari 2 butir soal cerita pokok bahasan Sistem Persamaan Linear Dua Variabel. Instrumen ketiga yakni pedoman wawancara yang digunakan setelah angket dan soal tes dikerjakan oleh subjek penelitian.

Data hasil angket self regulated learning akan mengelompokkan siswa ke dalam tiga kategori yakni siswa dengan self regulated learning tinggi, sedang, dan rendah. Selain itu, data hasil tes pemecahan masalah matematika akan dianalisis dan diberi skor sesuai dengan pedoman penskoran sehingga dari kedua instrumen tersebut akan dipilih responden wawancara. Responden dipilih dengan cara melihat skor angket self regulated learning dan skor tes pemecahan masalah matematika sehingga didapatkan dua siswa dari masing-masing kategori self regulated learning yang memiliki ketepatan jawaban sesuai dengan indikator pemecahan masalah menurut Polya.

\section{Hasil dan Pembahasan}

Angket disebarkan melalui link google form kepada seluruh siswa kelas VIII B dengan tujuan untuk menentukan kategori self regulated learning siswa yakni tinggi, sedang, dan rendah. Berdasarkan data hasil pengerjaan angket self regulated learning, diperoleh 2 siswa dengan self regulated learning rendah, 18 siswa dengan self regulated learning sedang, dan 13 siswa dengan self regulated learning tinggi di mana masing-masing memiliki interval skor capaian yang disajikan dalam Tabel 1 berikut. 
Tabel 1. Kategori Self Regulated Learning Subjek Penelitian

\begin{tabular}{|c|c|c|c|}
\hline No. & $\begin{array}{c}\text { Kategori } \\
\text { Penilaian }\end{array}$ & Banyak Siswa & Interval Skor Capaian Siswa \\
\hline 1. & Rendah & 2 siswa & $X<70$ \\
\hline 2. & Sedang & 18 siswa & $70 \leq X<110$ \\
\hline 3. & Tinggi & 13 siswa & $110 \leq X$ \\
\hline
\end{tabular}

Soal tes pemecahan masalah matematika diujicobakan kepada siswa yang telah mengisi angket self regulated learning. Selain itu, siswa diharuskan untuk mengerjakan soal dengan jawaban yang jelas dan runtut menurut tahapan Polya sesuai dengan format jawaban yang diberikan sebelumnya. Berdasarkan data hasil tes pemecahan masalah matematika, diperoleh hasil yang disajikan dalam Tabel 2 berikut.

Tabel 2. Hasil Tes Pemecahan Masalah Matematika Subjek Penelitian

\begin{tabular}{|c|c|c|c|c|c|c|c|c|}
\hline Soal & \multicolumn{4}{|c|}{ Soal 1 } & \multicolumn{4}{|c|}{ Soal 2 } \\
\hline Skor & $\mathbf{4}$ & $\mathbf{3}$ & $\mathbf{2}$ & $\mathbf{1}$ & $\mathbf{4}$ & $\mathbf{3}$ & $\mathbf{2}$ & $\mathbf{1}$ \\
\hline P1 & 26 & 7 & 0 & 0 & 24 & 8 & 1 & 0 \\
\hline P2 & 10 & 0 & 0 & 23 & 9 & 0 & 0 & 24 \\
\hline P3 & 16 & 14 & 2 & 1 & 16 & 6 & 10 & 1 \\
\hline P4 & 14 & 3 & 12 & 4 & 15 & 1 & 9 & 8 \\
\hline
\end{tabular}

Keterangan:

P1 : Tahap memahami masalah (understanding the problem)

P2: Tahap membuat rencana (devising the plan)

P3: Tahap melaksanakan rencana (carrying out the plan)

P4: Tahap melihat kembali (looking back)

Tabel 2 di atas menunjukkan banyaknya siswa yang melakukan tiap tahapan Polya pada masing-masing soal yang diberikan. Tiap tahapan memiliki skor maksimal 4 dan skor minimal 1 , sehingga skor maksimal yang didapatkan oleh siswa yakni 32.

Responden wawancara adalah 2 siswa dari tiap kategori self regulated learning dan masingmasing siswa dari tiap kategori tersebut dipilih berdasarkan skor angket self regulated learning dan jawaban tes pemecahan masalah matematika menurut tahapan Polya yang telah dikerjakannya. Responden wawancara terdiri dari 6 siswa dengan kategori tinggi (N1 dan N2), sedang (N3 dan N4), dan rendah (N5 dan N6). Daftar responden wawancara pada penelitian ini dapat dilihat pada Tabel 3 berikut.

Tabel 3. Subjek sebagai Responden Wawancara

\begin{tabular}{|c|c|c|c|c|}
\hline No. & Kode & $\begin{array}{c}\text { Kategori Self } \\
\text { Regulated } \\
\text { Learning }\end{array}$ & $\begin{array}{c}\text { Skor Tes } \\
\text { Regulated Learning Angket Self }\end{array}$ & $\begin{array}{c}\text { Semecahan } \\
\text { Masalah } \\
\text { Matematika }\end{array}$ \\
\hline 1. & N1 & Tinggi & 129 & 32 \\
\hline 2. & N2 & Tinggi & 127 & 32 \\
\hline 3. & N3 & Sedang & 108 & 23 \\
\hline 4. & N4 & Sedang & 97 & 22 \\
\hline 5. & N5 & Rendah & 69 & 14 \\
\hline 6. & N6 & Rendah & 56 & 17 \\
\hline
\end{tabular}

Berdasarkan penjelasan di atas, dapat dikatakan bahwa keenam subjek tersebut terdiri dari siswa dengan self regulated learning tinggi, sedang, dan rendah yang masing-masing terdiri dari dua 
orang siswa. Meskipun masing-masing kategori terdiri dari dua orang siswa, hasil analisis data menunjukkan bahwa keduanya memiliki hasil yang sama sehingga dapat langsung dideskripsikan menjadi tiga aspek sesuai dengan tiga kategori self regulated learning.

Hasil penelitian menunjukkan bahwa siswa pada setiap kategori self regulated learning memiliki kemampuan metakognisi yang berbeda-beda. Sesuai dengan pernyataan yang dikemukakan oleh Tayeb dan Putri (2017) yakni mengingat metakognisi sebagai suatu kemampuan untuk memahami dan memonitoring kegiatan berpikir terhadap diri sendiri, maka proses metakognisi tiap orang akan berbeda-beda menurut kemampuan dari tiap-tiap orang tersebut. Hal ini dapat dilihat dari cara mereka melakukan pemecahan masalah menurut Polya (1980) yakni (1) memahami masalah (understanding the problem), (2) membuat rencana (devising the plan), (3) melaksanakan rencana (carrying out the plan), dan (4) melihat kembali (looking back) dalam menyelesaikan soal cerita Sistem Persamaan Linear Dua Variabel (SPLDV). Subjek dalam penelitian ini terdiri dari siswa dengan self regulated learning tinggi, sedang, dan rendah di mana masing-masing kategori terdiri dari dua orang siswa. Meskipun masing-masing dari kategori terdiri dari dua orang siswa, hasil analisis data menunjukkan bahwa keduanya memiliki hasil serupa sehingga dapat langsung dideskripsikan menjadi tiga aspek sesuai dengan tiga kategori self regulated learning.

Siswa dengan self regulated learning tinggi mampu memenuhi ketiga indikator pada kemampuan metakognisi yakni perencanaan (planning), pemantauan (monitoring), dan evaluasi (evaluation). Hal ini ditunjukkan dengan adanya hasil pengerjaan tes pemecahan masalah matematika menurut tahapan Polya yaitu siswa mampu melaksanakan keempat tahapan dengan baik dan benar yakni tahap memahami masalah (understanding the problem), membuat rencana (devising the plan), melaksanakan rencana (carrying out the plan), dan melihat kembali (looking back). Hal ini sejalan dengan penelitian yang dilakukan oleh Harahap \& Harahap (2020) tentang siswa dengan self regulated learning tinggi. Pada penelitian tersebut menunjukkan bahwa subjek dapat menuliskan apa yang diketahui dan ditanyakan pada soal, tepat dalam membuat dan melaksanakan rencana, serta mampu menuliskan kesimpulan di bagian akhir jawaban sehingga dilakukan pemeriksaan ulang terhadap jawaban yang telah ditemukan.

Siswa dengan self regulated learning sedang hanya memenuhi dua indikator pada kemampuan metakognisi yakni perencanaan (planning) dan pemantauan (monitoring). Hal ini ditunjukkan dengan adanya hasil pengerjaan tes pemecahan masalah matematika menurut tahapan Polya di mana dua tahapan dilakukan dengan tepat yakni tahap melaksanakan rencana (carrying out the plan) dan melihat kembali (looking back), satu tahapan dilakukan dengan kurang tepat yakni tahap memahami masalah (understanding the problem), dan satu tahapan lainnya tidak dilakukan yakni tahap membuat rencana (devising the plan). Hal ini sedikit berbeda dengan penelitian yang dilakukan oleh Riyana \& Dewi (2021) tentang siswa dengan self regulated learning sedang. Pada penelitian tersebut menunjukkan bahwa subjek dapat menuliskan apa yang diketahui dan ditanyakan pada soal, dapat menentukan strategi yang tepat, akan tetapi kurang tepat dalam melaksanakan rencana, ditemukan kesimpulan pada akhir jawaban akan tetapi tidak dilakukan pemeriksaan ulang terhadap jawaban yang telah ditemukan.

Siswa dengan self regulated learning rendah hanya memenuhi satu indikator pada kemampuan metakognisi yakni perencanaan. Hal ini ditunjukkan dengan adanya hasil pengerjaan tes pemecahan masalah matematika menurut tahapan Polya yakni siswa hanya dapat melaksanakan satu tahapan dengan baik dan benar. Hal ini sejalan dengan penelitian yang dilakukan oleh Aini, Arum, \& Zulaicha (2016) tentang siswa dengan self regulated learning rendah. Pada penelitian tersebut 
menunjukkan bahwa subjek dapat menuliskan apa yang diketahui dan ditanyakan pada soal, kurang tepat dalam membuat dan melaksanakan rencana sehingga tidak ditemukan kesimpulan pada akhir jawaban dan tidak dilakukan pemeriksaan ulang terhadap jawaban yang telah ditemukan.

Sesuai dengan pernyataan Pintrich (dalam Mukhid, 2008) yakni self regulated learning merupakan suatu proses aktif dan konstruktif di mana pebelajar memiliki tujuan belajar mereka sendiri dan kemudian memantau, mengatur, mengontrol kognisi, perilaku, dan motivasi mereka sendiri. Oleh karena itu, dengan adanya metakognisi, siswa dimungkinkan dapat mengembangkan kemampuannya di setiap proses berpikirnya dalam melakukan pemecahan masalah matematika. Hal ini juga sejalan dengan salah satu kesimpulan dari penelitian yang dilakukan oleh Anggo (2011) yakni siswa yang mempunyai kemampuan metakognisi yang baik cenderung dapat memecahkan masalah yang dihadapinya dengan baik melalui pengerahan kesadaran dan pengaturan berpikir yang dilakukannya.

\section{Kesimpulan}

Kesimpulan dari penelitian ini yaitu keenam subjek yang terpilih sebagai responden wawancara memiliki skor angket dan skor tes yang berbeda-beda. Responden wawancara adalah 6 siswa yang meliputi ketiga kategori self regulated learning dan masing-masing kategori terdiri dari 2 siswa. Kedua siswa dengan self regulated learning tinggi yakni N1 memiliki skor angket 129 dan skor tes 32, sedangkan N2 memiliki skor angket 127 dan skor tes 32. Kedua siswa dengan self regulated learning sedang yakni N3 memiliki skor angket 108 dan skor tes 23, sedangkan N4 memiliki skor angket 97 dan skor tes 22. Kedua siswa dengan self regulated learning rendah yakni N5 memiliki skor angket 69 dan skor tes 14, sedangkan N6 memiliki skor angket 56 dan skor tes 17. Keenam subjek tersebut memiliki pemecahan masalah yang berbeda-beda dalam menyelesaikan soal cerita pokok bahasan Sistem Persamaan Linear Dua Variabel. Siswa dengan self regulated learning tinggi mampu memenuhi ketiga indikator kemampuan metakognisi yakni perencanaan (planning), pemantauan (monitoring), dan evaluasi (evaluation). Hal ini dapat dilihat dari cara siswa melakukan pemecahan masalah menggunakan keempat tahapan Polya yakni memahami masalah (understanding the problem), membuat rencana (devising the plan), melaksanakan rencana (carrying out the plan), dan melihat kembali (looking back) dengan baik dan benar. Siswa dengan self regulated learning sedang hanya mampu memenuhi dua indikator kemampuan metakognisi yakni pemantauan (monitoring) dan evaluasi (evaluation). Hal ini dapat dilihat dari cara siswa tersebut melakukan pemecahan masalah menggunakan tahapan Polya di mana dua tahapan dilakukan dengan tepat yakni tahap melaksanakan rencana (carrying out the plan) dan melihat kembali (looking back), satu tahapan dilakukan dengan kurang tepat yakni tahap memahami masalah (understanding the problem), dan satu tahapan lainnya tidak dilakukan yakni tahap membuat rencana (devising the plan). Siswa dengan self regulated learning rendah hanya mampu memenuhi satu indikator kemampuan metakognisi yakni perencanaan (planning). Hal ini dapat dilihat dari cara siswa tersebut melakukan pemecahan masalah menggunakan tahapan Polya di mana satu tahapan dilakukan dengan tepat yakni tahap memahami masalah (understanding the problem), dua tahapan lainnya dilakukan dengan kurang tepat yakni tahap melaksanakan rencana (carrying out the plan) dan melihat kembali (looking back), serta satu tahapan lainnya tidak dilakukan yakni tahap membuat rencana (devising the plan). 


\section{Daftar Pustaka}

Aini, Arum, P., dan Zulaicha, E. (2016). Pengaruh Terapi Bermain Walkie Talkie Terhadap Tingkat Kecemasan Akibat Hospitalisasi pada Anak Usia Prasekolah di RSUD Moewardi. Universitas Muhammadiyah Surakarta.

Anggo, Mustamin. 2011. Pemecahan Masalah Matematika Kontekstual Untuk Meningkatkan Kemampuan Metakognisi Siswa. Edumatika, 1(2).

Arum, R. P. (2017). Deskripsi Kemampuan Metakognisis Siswa SMA Negeri 1 Sokaraja dalam Menyelesaikan Soal Cerita Matematika Ditinjau dari Kemandirian Belajar Siswa. Journal of Mathematics Education. 3(1): 23-33.

Cahyani H. dan Setyawati R. W. (2016). Pentingnya Peningkatan Kemampuan Pemecahan Masalah melalui PBL untuk Mempersiapkan Generasi Unggul Menghadapi MEA. Seminar Nasional Matematika X. Universitas Negeri Semarang: 151-160.

Harahap, A. C. P., \& Harahap, S. R. (2020). Covid 19: Self regulated learning mahasiswa. Hunrla Pendidikan Dan Konseling, 10(1), 36-42. http://jurnal.uinsu.ac.id/index.php/alirsyad/article/view/7646/3478

Kuzzle, A. (2013). Patterns of Metacognitive Behavior During Mathematics Problem Solving in a Dynamic Geometry Environment. IEJME. 8(1): 20-40.

Novita, dkk. (2018). Metakognisi Siswa dalam Pemecahan Masalah Matematis Siswa SMA dalam Pembelajaran Berorientasi Etnomatematika Rejang Lebon. Jurnal Pendidikan Matematika Raflesia. 1 Juni 2018. 3(1): 41-54.

Polya, G. (1980). Mathematical Discovery. On Understanding, Learning and Teaching Problem Solving (Combined). Simultaneously.Riyana, M., \& Dewi, N. R. (2021). Analisis Kemampuan Pemecahan Masalah: Dampak Pembelajaran Inside Outside Circle (IOC) dengan Pendekatan Metaphorical Thinking. 8(1), 27-37.

Ruseffendi, E. T. (2006). Pengantar kepada Membantu Guru Mengembangkan Kompetensinya dalam Pengajaran Matematika untuk Meningkatkan CBSA. Bandung: Tarsito.

Thayeb, T., \& Putri, A. P. (2017). Kemampuan Metakognisi Untuk Meningkatkan Keterampilan Pemecahan Masalah Matematika Siswa Kelas VIII B Mts Madani Alauddin Paopao Kabupaten Gowa. MaPan, 5(1), 1-17. https://doi.org/10.24252/mapan.2017v5n1a1

Widjajanti, D. B. (2009). Kemampuan Pemecahan Masalah Matematis Mahasiswa Calon Guru Matematika: Apa dan Bagaimana Mengembangkannya. Seminar Nasional Matematika dan Pendidikan Matematika. 5 Desember 2009. Universitas Negeri Yogyakarta: 402-413.

Zimmerman, B. J. (1990). Self Regulated Learning and Academic Achievement: An Overview. Educational Psychologist. Larence Erlbaum Associates, Inc. 1(25): 3-17.

Mukhid. (2008). Strategi self-regulated learning. Tadrîs. 3(2) 